\title{
ANALISA PENGARUH CURRENT RASIO, SALES GROWTH, DEBT TO TOTAL ASET, DAYS SALES OUTSTANDING DAN TOTAL ASET TERHADAP RETURN ON ASET PADA PERUSAHAAN TEKSTIL YANG GO PUBLIK DI BURSA EFEK INDONESIA PERIODE 2017 - 2020
}

\author{
1*Muhammad Andrei Lesmono, ${ }^{2}$ Panji Galih Kusumo Adie \\ Universitas Pamulang, Tangerang Selatan, Banten, Indonesia \\ 1*dosen01696@unpam.ac.id, 22dosen011464@unpam.ac.id
}

\begin{abstract}
Abstrak
Industri tekstil dan garment di Indonesia menjadi salah satu tulang punggung industri manufaktur dan A industri prioritas nasional yang masih prospektif untuk dikembangkan. Industri tekstil dan garmen memberikan kontribusi cukup besar terhadap pertumbuhan ekonomi. Perekonomian Indonesia telah mencatat bahwa industri tekstil dan garment merupakan industri unggulan padat karya. World Integrated Trade Solution - Worldbank (WITS-Worldbank) melaporkan bahwa tahun 2019 nilai ekspor industri tekstil dan produk tekstil Indonesia menempati peringkat ke-16 atau sebesar 1,69\% dari pasar ekspor dunia. Industri ini memang termasuk 10 komoditas ekspor unggulan pada urutan kedua nilai ekspor nonmigas sesudah kelapa sawit, tapi nilai ekspornya mengalami penurunan yang diakibatkan permasalahan efisiensi dan kinerjanya yang kurang memuaskan. Penelitian ini dilakukan untuk mengetahui pengaruh Current Ratio, Sales Growth, Day Sales Outstanding, Debt to Total Asset dan Total Aset terhad ap Return on Asset Perusahaan Tekstil yang Go Publik Di Bursa Efek Indonesia periode 2017-2020. Metode pengambilan sampel yang d igunakan adalah teknik purposive sampling. Data diperoleh dari IDX (Indonesia Exchange). Pengujian Hipotesis dilakukan dengan menggunakan analisis regresi linier berganda yang meliputi Uji tTest, Uji F-Test dan Uji R2 setelah memenuhi uji asumsi klasik (Normalitas, Multikolinearitas, Autokorelasi dan Heteroskedastisitas). Hasil penelitian menunjukan bahwa Days Sales Outstanding berpengaruh positif dan signifikan terhadap Return on Asset. Secara bersamasama Current Ratio, Sales Growth, Debt to Total Asset, Day Sales Outstanding dan Total Asset berpengaruh signifikan terhadap Return on Asset.
\end{abstract}

Keywords: Current Rasio, Sales Growth, Day Sales Outstanding, Debt to Total Asset, Total Asset, Return on Asset

\begin{abstract}
The Textile and garment industry in Indonesia is one of The backbone of the manufacturing industry and is a national priority industry that is still prospective to be developed. The textile and garment industry contributes significantly to economic growth. The Indonesian economy has noted that the textile and garment industry is a leading, labor-intensive industry. The World Integrated Trade Solution - Worldbank (WITS - Worldbank) reports that in 2019 the export value of the Indonesian textile industry and textile products was ranked 16th or 1.69\% of the world export market. This industry is indeed includes in the top 10 export commodities in the second place in the value of non-oil and gas exports after palm oil, but the export value has decreased due to efficiency problems and unsatisfactory performance. This study was conducted to determine the effect of Current Ratio, Sales Growth, Day Sales Outstanding, Debt to Total Assets and Total Assets on Return oN Assets of Textile Companies that Go Public on The Indonesia Stock Exchange for 2017-2020 period. The sampling metode used is purposive sampling technique. Data obtained from IDX (Indonesia Exchange). Hypothesis testing was carried out using multiple liniear regression analysis which included $t$-test, F-test, and R2 test after fullfilling the classical assumption test (normality, multicollinearity, autocorrelation and heteroskedastisity). The result showed that Days Sales Outstanding had positive and significant effect on Return on Assets. Together, Current Ratio, Sales Growth, Debt to Total Assets, Day Sales Outstanding and Total Assets have a significant effect on Return on Assets.
\end{abstract}

Keyword: Current Ratio, Sales Growth, Debt to Total Assets, Day Sales Outstanding, Total Assets, Return on Assets 


\section{PENDAHULUAN}

Industri tekstil dan garment di Indonesia menjadi salah satu tulang punggung industri manufaktur dan merupakan industri prioritas nasional yang masih prospektif untuk dikembangkan. Industri tekstil dan garmen memberikan kontribusi cukup besar terhadap pertumbuhan ekonomi. Perekonomian Indonesia telah mencatat bahwa industri tekstil dan garment merupakan industri unggulan padat karya. World Integrated Trade Solution - Worldbank (WITSWorldbank) melaporkan bahwa tahun 2019 nilai ekspor industri tekstil dan produk tekstil Indonesia menempati peringkat ke-16 atau sebesar 1,69\% dari pasar ekspor dunia. Industri ini memang termasuk 10 komoditas ekspor unggulan pada urutan kedua nilai ekspor nonmigas sesudah kelapa sawit, tapi nilai ekspornya mengalami penurunan yang diakibatkan permasalahan efisiensi dan kinerjanya yang kurang memuaskan. Darmanto \& Ismawati K. (2020).

Menurut Kasmir (2016), rasio profitabilitas merupakan rasio untuk menilai kemampuan perusahaan dalam mencari keuntungan dan juga memberikan ukuran tingkat efektivitas manajemen suatu perusahaan. Perusahaan dapat memaksimalkan labanya apabila manajer keuangan perusahaan mengetahui faktorfaktor apa saja yang mempengaruhi profitabilitas. Semua faktor yang terdapat dalam sebuah perusahaan memiliki pengaruh terhadap kemampuan perusahaan dalam mendapatkan laba.

Menurut Kasmir (2016), rasio likuiditas adalah rasio yang menunjukkan kemampuan perusahaan dalam membayar utang-utang jangka pendeknya yang jatuh tempo atau rasio untuk mengetahui kemampuan perusahaan dalam membiayai dan memenuhi kewajiban pada saat ditagih. Semakin rendah nilai Current Ratio, maka akan mengindikasikan ketidakmampuan perusahaan dalam memenuhi kewajiban jangka pendeknya, sehingga hal ini mempengaruhi tingkat profitabilitas perusahaan, dimana perusahaan yang tidak mampu memenuhi kewajibannya akan dikenai beban tambahan atas kewajibannya. Hasil penelitian yang dilakukan oleh Nurcahayani (2014) mengatakan bahwa likuiditas berpengaruh positif terhadap profitabilitas. Hal yang berlawanan diungkapkan oleh Anissa \& Ariana A. (2019) yang mengatakan bahwa rasio likuiditas tidak berpengaruh terhadap profitabilitas.

Pertumbuhan penjualan adalah kenaikan jumlah penjualan dari tahun ke tahun atau dari waktu ke waktu (Kennedy, dkk., 2013). Penjualan memiliki pengaruh yang strategis bagi sebuah perusahaan, karena penjualan yang dilakukan harus didukung dengan harta atau aktiva dan bila penjualan ditingkatkan maka aktiva pun harus ditambah, dengan mengetahui penjualan dari tahun sebelumnya, perusahaan dapat mengoptimalkan sumber daya yang ada. Hal ini didukung oleh penelitian yang dilakukan oleh Anissa \& Ariana A. (2019) yang mengatakan bahwa pertumbuhan penjualan berpengaruh positif.

Jika perusahaan mempunyai beban hutang yang bertambah, namun investasi yang dibiayai dari hutang itu memberikan penghasilan yang lebih besar dibanding dengan biaya hutangnya, maka keadaan itu akan menguntungkanbagi perusahaan. Karena dengan semakin besar hutang berarti semakin besar pula kewajiban yang dikeluarkan terutama untuk membayar bunga hutang. Bagi perusahaan hutang memiliki beberapa keuntungan antara lain bunga yang dibayar dapat mengurangi beban pajak dan juga menaikan nilai perusahaan. Kelemahan hutang bagi perusahaan yaitu semakin tinggi rasio hutang (Debt to Equity Ratio atau Debt to Total Aset), maka semakin tinggi resiko perusahaan, bila perusahaan mengalami kesulitan keuangan dan laba operasi tidak sanggup menutupi kewajiban.

Semakin besar skala perusahaan maka profitabilitas perusahaan juga akan meningkat, tetapi pada titik tertentu atau ukuran tertentu akan menurunkan menurunkan laba (Profit) perusahaan.

Dari penjabaran di atas, penulis tertarik untuk melakukan sebuah penelitian dengan judul "ANALISIS PENGARUH CURRENT RATIO, SALES GROWTH, DEBT TO TOTAL ASSET, DAYS SALES OUTSTANDING DAN TOTAL ASSET TERHADAP RETURN ON ASSET PADA PERUSAHAAN TEKSTIL YANG GO PUBLIK DI BURSA EFEK INDONESIA PERIODE 2017 - 2020". 


\section{Rumusan Masalah}

Dari penjabaran latar belakang di atas, penulis menarik beberapa rumusan masalah, yaitu :

1. Bagaimana pengaruh Current Ratio (CR) terhadap Return On Asset (ROA)?

2. Bagaimana pengaruh Sales Growth (SG) terhadap Return On Asset (ROA)?

3. Bagaimana pengaruh Debt to Total Asset (DTA) terhadap Return On Asset (ROA)?

4. Bagaimana pengaruh Days Sales Outstanding (DSO) terhadap Return On Asset (ROA)?

5. Bagaimana pengaruh Total Asset (TA) Perusahaan terhadap Return On Asset (ROA)?

6. Bagaimana pengaruh Debt To Total Asset (DTA), Current Ratio (CR), Sales Growth (SG), Days Sales Oustanding (DSO), Total Aset (TA) secara simultan terhadap Return On Asset (ROA).

\section{Tujuan Penelitian}

Berdasarkan perumusan masalah di atas, maka tujuan penelitian ini adalah sebagai berikut :

1. Untuk mengetahui pengaruh Current Ratio (CR) terhadap Return on Asset (ROA)

2. Untuk mengetahui pengaruh Sales Growth terhadap Return on Asset (ROA)

3. Untuk mengetahui pengaruh Debt to Total Aset (DTA) terhadap Return on Asset (ROA)

4. Untuk mengetahui pengaruh Days Sales Outstanding (DSO) terhadap Return on Aset (ROA)

5. Untuk mengetahui pengaruh Total Aset (TA) terhadap Return on Asset (ROA)

6. Untuk mengetahui pengaruh Debt to Total Aset (DTA), Current Ratio (CR), Sales Growth (SG), Days Sales Oustanding (DSO), Total Aset (TA) secara simultan terhadap Return on Asset (ROA).

\section{METODE}

Dalam melakukan penelitian dibutuhkan adanya suatu metode, cara atau taktik sebagai langkah-langkah yang harus ditempuh oleh seorang peneliti dalam memecahkan suatu permasalahan untuk mencapai suatu tujuan. Adapun metode yang penulis gunakan dalam penelitian adalah metode deskriptif kuantitatif.
Menurut Sugiyono (2016:6), metode penelitian dapat diartikan sebagai cara ilmiah untuk mendapatkan data yang valid dengan tjuan dapat ditemukan, dikembangkan dan dibuktikan suatu pengetahuan tertentu sehingga pada gilirannya dapat digunakan untuk memahami, memecahkan dan mengantisipasi masalah dalam bidang pendididkan.

Dengan metode ini penulis bermaksud mengumpulkan data historis dan mengamati secara saksama mengenai aspek-aspek tertentu yang berkaitan dengan masalah yang sedang diteliti oleh penulis sehingga akan memperoleh data-data yang dapat mendukung penyusunan laporan penelitian. Data-data yang diperoleh tersebut kemudian diproses dan dianalisi lebih lanjut dengan dasar teori yang telah dipelajari sehingga memperoleh gambaran mengenai objek tersebut dan dapat ditarik kesimpulan mengenai masalah yang diteliti.

\section{Variabel Operasional}

Definisi operasional variable adalah pengertian variable (direpresentasikan dalam definisi konsep), yang sebenarnya merupakan definisi operasional yang sebenarnya dalam lingkup objek penelitian ini adalah variable bebas dan variable terikat.

1. Variabel Dependen (Y)

Variabel dependen atau variable terikat merupakan variable yang dipengaruhi atau menjadi akibat, karena adanya variable bebas, Sugiyono (2017). Variabel terkait dalam penelitian ini adalah ROA (Return On Assets). ROA (Return On Assets) diperoleh dengan cara membandingkan laba bersih setelah pajak terhadap total aktiva. ROA merupakan salah satu bentuk dari rasio profitabilitas yang dimaksud untuk dapat mengukur kemampuan perusahaan dengan keseluruhan dana yang ditanamkan dalam aktiva yang digunakan untuk operasi perusahaan untuk menghasilkan keuntungan. Rasio ini disebut juga rentabilitas ekonomis, merupakan kemampuan perusahaan dalam menghasilkan laba dengan semua aktiva yang dimiliki oleh perusahaan. Return On Asset (ROA) merupakan pendekatan yang di gunakan untuk mengukur tingkat pengembalian asset. Pada penelitian ini, 
ROA di hitung dengan mengunakan rumus:

$$
\text { Return On Asset }=\frac{\text { Net Income After Tax }}{\text { Total Asset }}
$$

2. Variabel Independen (X)

Variabel ini sering disebut sebagai variabel stimulus, predictor, antecedent. Dalam Bahasa Indonesia sering disebut variabel bebas. Pengertian variabel independen (bebas) menurut Sugiyono (2016:39) "Variabel bebas adalah merupakan variabel yang mempengaruhi atau menjadi sebab perubahannya atau timbulnya variabel dependen (terikat).

a. Current Ratio

$\begin{array}{ccr}\text { Current } & \text { Ratio } & \text { adalah } \\ \text { Kemampuan } & \text { perusahaan } & \text { untuk }\end{array}$ memenuhi kewajiban yang harus segera dipenuhi atau dengan kata lain untuk memenuhi kewajiban jangka pendeknya. Current Ratio dihitung dengan Rumus:

Current Ratio $=\underline{\text { Current Asset }}$ Current Liabilities

b. Sales Growth

Sales growth pendapatan penjualan yang diukur berdasarkan perbandingan net sales periode sekarang minus periode sebelumnya terhadap net sales periode sebelumnya. Rasio ini dapat di rumuskan sebagai berikut:

$$
\text { Sales Growth }=\frac{\text { Sales } t 1-\text { Sales to }}{\text { Sales to }}
$$

c. Debt to Total Asset

Debt to Total Aset menunjukan kemampuan perusahaan dalam memenuhi kewajiban hutang (Total Debt) terhadap Total Aset. Debt to Total Aset (DTA) di hitung dengan membagi jumlah total hutang dengan Total Aset. Rasio ini dapat di rumuskan sebagai berikut:

$$
\text { Debt to Total Asset }=\frac{\text { Total Debt }}{\text { Total Asset }}
$$

\section{d. Days Sales Outstanding}

Day Sales Outstanding (DSO) sama dengan Average Collection Period. Rasio ini menujukan rata - rata jangka waktu penerimaan piutang, semakin besar DSO maka semakin lama pengembalian piutangnya. Rasio ini dapat di rumuskan sebagai berikut:
Days Sales Outstanding $=\underline{\text { Receiveable }}$

Sales $/ 365$

e. Total Aset

Ukuran perusahaan menunjukan

seberapa besar total asset yang

dimiliki

Size $=$ LN Total Asset

Metode analisis data yang digunakan dalam penelitian ini adalah Metode Regresi Linier Berganda, yaitu untuk menghitung besarnya pengaruh secara kuantitatif dari suatu perubahan kejadian variabel $X$ terhadap variabel $Y$. Dalam penggunaan persamaan regresi terdapat beberapa asumsi-asumsi yang harus dipenuhi untuk kemudian dapat di analisis. Asumsi tersebut menggunakan Uji Asumsi Klasik, Koefisien Determinasi (R2), Uji Signifikansi Simultan (Uji Statistik F), dan Uji Signifikansi Parameter Individual (Uji Statistik T) agar hasil pengujian dapat diinterpretasikan dengan tepat.

\section{HASIL DAN PEMBAHASAN}

Obyek dalam penelitian ini adalah perusahaan tekstile yang terdaftar pada Bursa Efek Indonesia selama periode pengamatan 2017 - 2020. Data yang digunakan dalam penelitian ini adalah data sekunder yang diperoleh dari laporan keuangan yang dipublikasikan oleh Bursa Efek Indonesia melalui IDX tahun 2021. Dalam penelitian ini semua variabel yaitu, Debt to Total Asset, Current Rasio, Sales Growth, Total asset, Day Sales Outstanding dan Return on Asset adalah dari data tahunan. Penelitian ini menggunakan sampel 43 data.

Sebelum dilakukan pengujian hipotesis, terlebih dahulu akan di sajikan mengenai deskripsi atau kondisi distribusi masingmasing variabel penelitian. Deskripsi ini akan memperlihatkan kecenderungan yang terjadi pada sebaran masing-masing variabel penelitian. Statistik secara deskriptif menjelaskan variabel penelitian meliputi Jumlah $(\mathrm{N})$, nilai minimum, nilai maksimum, nilai rata - rata (mean), nilai peyimpangan standar (standar deviasi).

Sebelum melakukan pengujian regresi linier, perlu dilakukan terlebih dahulu pengujian asumsi klasik. Dalam uji klasik data harus terdistribusi normal, tidak mengandung multikolinearitas, autokorelasi dan heteroskedastisitas. 
Hasil perhitungan regresi Linier berganda digunakan untuk menganalisis data yang telah di peroleh agar dapat mengetahui sejauh mana pengaruh variabel Current Ratio (CR), Sales Growth (SG), Debt to Total Aset (DTA), Days Sales Outstanding (DSO) dan Total Aset (TA) secara bersama-sama berpengaruh terhadap Return On Asset (ROA) dengan mengunakan bantuan software SPSS versi 25.

Tabel 1. Hasil Uji Parsial (Uji t)

\begin{tabular}{|c|c|c|c|c|}
\hline $\begin{array}{c}\text { Variabel } \\
\text { bebas }\end{array}$ & $\mathbf{t}_{\text {hitung }}$ & Sig & Ho & H1 \\
\hline CR & -.231 & $\begin{array}{c}0,81 \\
8\end{array}$ & Diterima & Ditolak \\
\hline SG & .627 & $\begin{array}{c}0.53 \\
5\end{array}$ & Diterima & Ditolak \\
\hline DTA & $\begin{array}{c}.791 \\
17.56\end{array}$ & $\begin{array}{c}.434 \\
.000\end{array}$ & $\begin{array}{c}\text { Diterima } \\
\text { Ditolak } \\
\text { DSO } \\
\text { TA }\end{array}$ & $\begin{array}{c}\text { Ditolak } \\
\text { Diterima } \\
\text { Ditolak }\end{array}$ \\
\hline
\end{tabular}

\section{PEMBAHASAN}

Dari hasil perhitungan uji parsial diperoleh nilai t hitung sebesar $-0,231$, yaitu lebih kecil dari t tabel sebesar 2,021. Dan nilai signifikansi sebesar 0,818, yaitu lebih besar dari nilai signifikansi 0,05 atau $5 \%$. Maka dapat disimpulkan Current Rasio (CR) tidak memiliki pengaruh terhadap Return on Aset (ROA). Hasil penelitian yang dilakukan oleh Nurcahayani (2014) mengatakan bahwa likuiditas berpengaruh positif terhadap profitabilitas. Hal yang berlawanan diungkapkan oleh Anissa \& Ariana A. (2019) yang mengatakan bahwa rasio likuiditas tidak berpengaruh terhadap profitabilitas.

Dari hasil perhitungan uji parsial diperoleh nilai t hitung sebesar 0,627,yaitu lebih kecil dari t-tabel sebesar 2,021. Dan nilai signifikansi sebesar 0,535, yaitu lebih besar dari 0,05 atau $5 \%$. Maka disimpulkan Sales Growth tidak memiliki pengaruh terhadap Return on Aset (ROA). Penelitian yang dilakukan oleh Anissa \& Ariana A. (2019) yang mengatakan bahwa pertumbuhan penjualan berpengaruh positif terhadap profitabilitas. Sedangkan oleh Meidiyustiani (2016) yang mengatakan bahwa pertumbuhan penjualan tidak berpengaruh terhadap profitabilitas.

Dari hasil perhitungan uji parsial diperoleh nilai t hitung sebesar 0,791, yaitu lebih kecil dari t tabel sebesar 2,021. Dan nilai signifikansi sebesar 0,434 , yaitu lebih besar dari 0,05atau $5 \%$. Maka dapat disimpulkan Debt to Total Aset (DTA) tidak memiliki pengaruh terhadap Return on Aset (ROA). Penelitian dari Afrinda, dkk, (2012), yang menunjukkan bahwa debt to total asset secara parsial berpengaruh signifikan terhadap return on asset.

Dari hasil perhitungan uji parsial diperoleh nilai t hitung sebesar 17,562 , yaitu lebih besar dari t-tabel sebesar 2,021. Dan nilai signifikansi sebesar 0,001, yaitu lebih besar dari nilai signifikansi 0,05 atau $5 \%$. Maka dapat disimpulkan Days Sales Outstanding (DSO) memiliki pengaruh dan signifikan terhadap Return on Aset (ROA). Penelitian wahyuni (2012), menunjukkan Days Sales Outstanding yang semakin lama mengakibatkan ROA cenderung tinggi, sehingga Days Sales Outstanding cenderung berpengaruh positif terhadap ROA.

\section{PENUTUP}

Berdasarkan hasil penelitian dapat disimpulkan menjadi sebagai berikut :

1. Current Ratio (CR) tidak memiliki pengaruh terhadap Return On Asset (ROA).

2. Sales Growth (SG) tidak memiliki pengaruh terhadap Return On Asset (ROA).

3. Debt to Total Aset (DTA) tidak memiliki pengaruh terhadap Return On Asset (ROA).

4. Days Sales Outstanding memiliki pengaruh signifikan terhadap Return on Asset.

5. Total Aset(TA) tidak memiliki pengaruh terhadap Return on Aset (ROA)

6. Current Ratio (CR), Sales Growth (SG), Debt to Total Aset (DTA), Days Sales Outstanding (DSO),Total Aset (TA) secara simultan memiliki pengaruh signifikan terhadap Return On Asset (ROA).

\section{DAFTAR PUSTAKA}

Afrinda, Nydia dan Marlina Widayanti. 2012. Aanlisis Pengaruh Likuiditas dan Solvabilitas Terhadap Profitabilitas pada Perusahaan Makanan dan Minuman yang Terdaftar di Bursa Efek Indonesia.Jurnal Manajemen, Vol 1, No 1.

Anissa, Anya Riana. 2019. Pengaruh Perputaran Modal Kerja, Pertumbuhan Penjualan dan Likuiditas Terhadap Profitabilitas Pada Perusahaan Retail Yang Terdaftar Di Bursa Efek 
Indonesia. Jurnal Riset Manajemen Sains Indonesia (JRMSI). Vol. 10, No.1.

Darmanto \& Ismawati K. (2020) Kinerja Perusahaan Tekstil dan Garment. Jurnal Akuntansi dan Pajak, Vol. 21, No. 1, 2020

Debt To Asset Ratio (DAR), Terhadap Return on Asset (ROA), serta Dampaknya Terhadap Nilai Perusahaan (studi terhadap perusahaan jasa penunjang. Jurnal Ilmiah Manajemen Forkamma, Vol.1, No.2 ,Februari 2018. Halaman (87-112)

Fahmi, Irfam. (2012). Analisis Laporan Keuangan. Cetakan keempat. Bandung: Alfabeta. Fahmi, Irfam. (2013). Pengantar Manajemen Keuangan Teori dan Soal Jawaban. Bandung: Alfabeta.

Ghozali, I. (2013). Aplikasi Analisis Multivariente Dengan Program SPSS 21. Semarang: BadanPenerbit Universitas Diponegoro.

Harjayanti D. R. \& Pujiati P. (2020). Current Ratio (CR) dan Debt to Asset Ratio (DAR) terhadap Return On Assets (ROA) pada PT. Indocement Tunggal Prakarsa Tbk Periode 2009-2018. Jurnal Madani Vol. 3, No. 1, 2020

Hayati K., Dkk. (2019). Pengaruh Inventory Turnover, Sales Growth, dan Liquidity Terhadap Profitabilitas pada PT. Sumber Alfaria Trijaya, Tbk Tanjung Morawa Periode 2013- 2017. Universitas Prima Indonesia Riset dan Jurnal Akuntansi, Vol. 3, No. 1, 2019

Herliana D. (2021). Pengaruh Current Ratio Dan Debt to Equity Ratio terhadap Return On. Assets pada Perusahaan Pertambangan Subsektor Batubara yang Terdaftar di BEI 2016-2018. Jurnal mahasiswa Unsriya, Vol 1, No. 1, 2021.

Kasmir. (2015). Analisis Laporan Keuangan. Jakarta: PT. Raja Grafindo Persada.

Kasmir. (2016). Analisis Laporan Keuangan. Jakarta: Raja Grafindo Persada.

Kennedy, Nur Azlina dan Anisa Ratna Suzana. 2013. Faktor-Faktor yang Mempengaruhi Struktu Modal pada Perusahaan Real Estate and Property yang Go Public di Bursa Efek Indonesia. Jurnal Akuntasi, h:1-10.

Meidiyustiani, Rinny. 2016. Pengaruh Modal Kerja, Ukuran Perusahaan,
Pertumbuhan Penjualan dan Likuiditas Terhadap Profitabilitas pada Perusahaan Manufaktur Sektor Industri Barang Konsumsi yang terdaftar di Bursa Efek Indonesia (BEI) Periode Tahun 2010 2014. Jurnal Akuntansi dan Keuangan Universitas Budi Luhur, Vol. 5, No. 2, Oktober 2016 Mulyani dan Ajizah E. (2019), Analisis Pengaruh Current Ratio dan Debt To Asset Ratio,Debt To Equity Ratio terhadap Return On Asset pada Perusahaan Yang Terdaftar di Bursa Efek Indonesia (BEI). The Asia Pacific journal of Management Studies, vol. 6,No. 1,Januari-April 2019 hal (19-28)

Munawir. (2014). Analisis Laporan Keuangan. Yogyakarta: Liberty.

Nababan, D., Putra, IGS., (2018). Analysis contribution and effectiveness of local taxes toward original regional income at Bandung City. International Journal of Engineering and Technology (UAE). 204-207.

Noryani, Y. B. G., et al. (2020). Did ISO 45001, ISO 22000, ISO 14001 and ISO 9001 Influence Financial Performance? Evidence from Indonesian Industries. PalArch's Journal of Archaeology of Egypt/Egyptology, 17(7), 6930-6950.

Nurcahyani, R. (2014). Analis Pengaruh Struktur Modal Terhadap Profitabilitas (Studi Pada Perusahaan Manufaktur Yang Terdaftar Di Bursa Efek Indonesia Pada Tahun 2010 2012) Jurnal Akuntansi, 3(4).

Pradifta Sulistya Nugraha P. S., A. Diponegoro A. M. H (2016). Analisis Pengaruh Sales Growth, REO, Size, TATO, dan Current Ratio terhadap ROA dan ROA terhadap Beta Akuntansi. Journal of Management, Vol. 5, No. 1, 2016

Sinaga O., Dkk. Pengaruh Current Ratio, total Aset turn over, dan ukuran perusahaan terhadap profitabilitas perusahaan manufaktur pada sektor industri barang dan konsumsi yang terdafatar di bursa efek indonesia periode 20142018. Jurnal Inovasi,16 (2), 2020; 179191

Solihin D. (2019) Pengaruh Current Ratiodan Debt To Equity Ratio Terhadap Return OnAsset (ROA)Pada PT Kalbe Farma Tbk, Kreatif Jurnal Ilmiah Prodi 
Manajemen Universitas

Pamulang,Volume 7, No 1 Juni 2019,Halaman115-122

Sugiyono. (2010). Statistika untuk Penelitian. Bandung: Alfabeta.

Sugiyono. (2017). Metode Penelitian Kuantitatif, Kualitatif, dan R\&D. Bandung: Alfabeta

Sukadana I. K. A,Triaryati N. (2018) Pengaruh Pertumbuhan Penjualan, Ukuran Perusahaan, dan Leverage terhadap Profitabilitas pada Perusahaan Food and Beverage BEI. E- Jurnal Manajemen Unud,Vol. 7, No.11, 2018

Wahyuni. 2012. Pengaruh Inventory Turnover, Days Sales Outstanding dan
Debts Ratio Terhadap Return On Assets (ROA) pada PT Unilever Indonesia Tbk Tahun 2008- 2011. Tugas Akhir Program Studi Akuntansi pada Fakultas Ekonomi Universitas Negeri Yogyakarta, Yogyakarta.

Wartono T. (2018) Pengaruh Current Ratio (CR) dan Debt to Equuity Ratio (DER) terhadap Return On Aset (ROA). Jurnal Kreatif, Vol.6, No. 2, 2018 Widodo A. (2018). Analisis Pengaruh Current Ratio (CR), Total Asset Turnover (TATO),dan

www.idx.co.id 